ESSAYS

Mitchell Rolls

\title{
Flora, Fauna and Concrete: \\ Nature and Development in Walkabout magazine (Australia: 1934-1978)
}

\section{Abstract}

The popular Australian magazine Walkabout, published between 1934 and 1978, appears at first glance an exemplar of robust nationalism; a purveyor of simple messages extolling Australia's beauty, bountyfulness, potential for development, and empty spaces lying in wait for peopling by resourceful types. In one of the few critiques of the magazine Glen Ross argues that Walkabout's "narration of the nation" promoted modernisation, particularly of the outback, and a nationalism based on white masculine progress $\left(28\right.$; and passim). ${ }^{1}$ Yet the impressionistic "narrative strategies" and "rhetorical machinery" (Geertz 2) advocating progress are not seamless. There are asides that qualify, annexes where a contrary stance is voiced, even developed, and if not that, the inclusion of concerns and interests that create openings and suggest alternative agendas, all of which mitigate if not guard against a simple, foreclosing boosterish nationalism.

It is the tension in the pages of Walkabout between advocacy for industrial progress and its interest in native flora and fauna that this paper addresses. Or more specifically, and using an analytical model developed for interpreting nineteenth-century Victorian novels, the sort of reading practices that might shed light on these tensions. This is foregrounded in discussion challenging Ashcroft's and Salter's privileging of "fictional narratives" in the imagining of Australia (19). It is argued here that Walkabout furnished material upon which many readers could imagine a hitherto mostly unknown Australia, and that this imagining predates the imaginative catalyst - the Mabo decision - proposed by Ashcroft and Salter. The concern is not with charting the broader historical and socio-cultural contexts in which Walkabout was situated and how this changed over time, but in seeking the significance if any of contributions that appear to sit awkwardly with more dominant themes.

1 For a critique of Ross's reading of Walkabout see Rolls (2010a; 2010b). 


\section{Tension and Contrast}

In the lead up to the 2010 Australian federal election, Bob Katter, the idiosyncratic independent member for the seat of Kennedy in north Queensland, seized the opportunity for stump oratory. Unsurprisingly he included one of his perennial interests, that of "turning back the rivers" in order to irrigate the arid regions of western Cape York, the gulf country and beyond (ABC 2010b). The blue print for this scheme, variously described as "The Greatest Scheme of All" and "Australia's Next Great National Project", was drafted by J.J.C. Bradfield, the engineer who amongst much else had input into the design of the Sydney Harbour Bridge and oversaw its construction. ${ }^{2}$ Bradfield presented his proposal to the Queensland state government in 1938. In it he advocated harnessing several seasonally monsoon swollen rivers whose waters flow eastwards and "wastefully" into the sea, so as to direct their flow west- and southwards instead. Such a course of action would not only bring the excess river water to this region of arid Australia, but would also precipitate climate change by increasing annual rainfall (through increased evaporation). Bradfield anticipated his scheme would dramatically increase primary production, and allow for rapid growth of Australia's population. Writing for a 1941 edition of the popular magazine Walkabout Bradfield opined that in order "to hold what we have ... we must have a vastly greater population - say 40 millions 40 years hence. We must plan now how to get these millions" (15). ${ }^{3}$

Although Bradfield's vision was certainly writ large, faith in the transformational powers of irrigation and its supporting infrastructure (such as large reservoirs) is a recurrent theme throughout much of Walkabout. So too, in one way or another, is the understanding that Australia must "populate or perish." To this end Walkabout can be read for its passion for boosting primary production and rural development, the latter whether through technology, in-

2 Bradfield laid claim to designing the Sydney Harbour Bridge, but so too did others, and it appears that at the very least the final design bears the influence of a number of people (Spearritt).

3 Some 70 years after Bradfield's proposal the Tasmanian premier announced a similarly grandiose scheme (albeit on a smaller scale) to pipe water to the state's dry midlands in anticipation of it becoming "the food bowl of the nation" (see ABC 2010a). 
dustry and / or population growth, particularly in rural, remote and northern Australia. Yet whilst there is a discernible boosterish teleology within the loose constraints - accurately described by Michael Cathcart as "cheery bush nationalism" (215) - shaping Walkabout's miscellany, other concerns and interests are also evident. These are not necessarily different voices, although there are those too, but even in the most tacit form acknowledgments exist of certain costs accompanying economic growth, and more explicitly, the significance of Australia's native flora and fauna.

Walkabout was a monthly magazine launched in November 1934. Save for a combined July-August issue in 1972 it published without interruption until 1974, including throughout the war years when quality paper was hard to source and subject to quota. In 1977 an attempt was made to revive the magazine, but it folded with the October 1978 edition after three consecutive issues. Sold through subscription - to individuals, school libraries and other institutions - and on open sale through newsagencies and bookstores throughout Australia and New Zealand, its zenith was the 1965-66 financial year with average monthly sales of 46,908 copies, the 1965 special Christmas issue selling 65,000 copies, and having subscribers in 100 countries (Australian National Travel Association 1966). Throughout its run it was also distributed internationally to Australian High Commissions, embassies, and overseas tourist offices.

It was an early initiative of the Australian National Travel Association (ANTA). Established on $25^{\text {th }}$ March 1929, the association's purpose was to provide a national body that would oversee and coordinate the promotion of tourism both within and to Australia. A corollary of this promotion was to market Australia as a desirable continent to emigrate to and in which to invest (ANTA 1929). ${ }^{4}$ Although Walkabout was supposedly one of ANTA's key promotional strategies, under the editorship of Charles Holmes, who was also ANTA's director and author of the 1932 book We Find Australia, the magazine had from the outset a wider objective. And it was this objective,

4 Most of the Australian National Travel Association board meeting minutes and Walkabout files were uncatalogued and unsorted when this material was read in May 2009 and November 2010. Much of the material was held in forty three boxes marked "Beresford", after the donor Don Beresford. Thanks to Don Beresford and Mitchell Library staff for arranging access to the uncatalogued collection. 
rather than a more overt promotional and touristic focus or nationalist propaganda that took precedence. ${ }^{5}$ Chas (Charles) Lloyd Jones, the acting chairman of the ANTA board - and chairman of the David Jones department store - made this explicitly clear in the inaugural edition's editorial:

[I]n publishing "Walkabout," we have embarked on an educational crusade which will enable Australians and the people of other lands to learn more of the romantic Australia that exists beyond the cities and the enchanted South Sea Islands and New Zealand. (Jones)

To this end from the very beginning Walkabout lent towards the natural sciences and natural history, albeit in popular form. Cemented by Holmes' lengthy stint as editor - he retired from the editorship in August 1957 - it was an approach that endured throughout most of Walkabout's long run. ${ }^{6}$

Examples in Walkabout of the tensions between extolling development and interest in natural features potentially threatened by it are both explicit and implicit. They are found within articles, in the juxtaposition of articles with different emphases in particular issues, and across issues, and in those of differing subject matter. Examples of the latter are the articles promoting extractive industries such as mining, forestry and related commerce, and fishing; as well as assorted pastoral industries and agriculture, including wool-growing and cropping. Such articles are unselfconsciously juxtaposed with those focussing on natural history and describing in detail the specificities of assorted flora and fauna. The following are two typical ex-

5 In addition to Walkabout, the Australian National Travel Association published a vast and varied literature, including booklets, posters, yearbooks, and distributed thousands of photographs, that amply fulfilled ANTA's promotional and touristic charter. This material freed Walkabout to pursue interests befitting a geographical magazine, which facilitated the showcasing of Australia through a more educative and less explicitly advertising-come-touristic marketing approach. To some extent it also insulated Walkabout from the need to respond to the vicissitudes of tourism trends. But see also fn 6 .

6 From the mid to late 1960s, and for a range of reasons, the magazine no longer paid its own way, lost its original focus and was more explicitly geared towards marketing both tourism and travel. See collection of letters from Editor Wally Crouch (ANTA 1971). It is the decades preceding this development that are the principal focus of this paper. 
amples of ostensibly conflicting and disparate material. The April 1940 issue amongst other contributions features a goanna as the cover image ("Goanna"), an article on the iron ore deposits at Yampi sound (Ewers), one describing the frogmouth bird (Harvey), another a species of ray (Patterson), and another describing the discovery of shale-oil deposits in Australia and the workings at Glen Davis near Lithgow in New South Wales (Samuel). In a 1942 issue Christopher Barlow writes of forest clearing in New Zealand to ready land for grazing and farming:

For most surely the bushman stands at the head of New Zealand's pioneers. With destruction and fire he blazed the trail for New Zealand's cattle and sheep and wheat. His was the task of wresting the land from the ancient forest strongholds - and his is the victory. (33)

The same issue provides a photographic article on Australian lizards ("Australia and the South Seas") and an illustrated article on Australian possums (Curtis 1942). Contrasts like these within single issues - articles supporting the destruction of habitat and those describing its dependent flora and fauna - are typical of Walkabout, not exceptional.

The promotion of progress and extolling the virtues of modernity was of course nothing new and had long antecedents. Even in the early nineteenth century it was already well rehearsed advocacy. In his second annual address to Congress US President Andrew Jackson rhetorically asked:

What good man would prefer a country covered with forests and ranged by a few thousand savages to our extensive Republic, studded with cities, towns, and prosperous farms embellished with all the improvements which art can devise or industry execute...? (Jackson)

On a different continent and 118 years later Allan Callaghan, an agricultural scientist, Rhodes Scholar and the then Principal of Roseworthy Agricultural College in South Australia, expounded similar sentiments in the pages of Walkabout: His article commends the draining and clearing of 4,500 acres of land in south-eastern South Australia, so as to transform it from uneconomical wasteland to realised potential, or as its title suggests, "From Tea-Tree Swamp to Pasture":

... [S]oon 2,500 cows will graze where once stood impenetrable teatree. The transformation from tea-tree swamp to pasture will then be 
complete, and thirty-three families in modern homes will be the living testimony to man's triumph over swamp and scrub. (Callaghan 32)

Many contributors, however, were more equivocal than Callaghan when discussing the destruction of flora and fauna. The year before Callaghan (1948) gladly foresaw a prosperous farming community emerging from a tea-tree swamp, R. Emerson Curtis, an artist, illustrator and cartoonist, wrote more generally of the need to better manage and conserve Australia's standing timber in light of its plundering during the war. He argued the urgent need for better forestry management practices, reafforestation projects, and for the cessation of the ringbarking and clearing of trees undertaken by pastoralists. The latter he warned set in train processes that devastate the land's viability:

Flood water and wind, sweeping unchecked over areas of once wellwooded country, have stripped away the rich top soils and rendered barren and useless great stretches of once fertile land. (29)

This warning of consequences is in an article otherwise extolling the virtues of Australian timber and supportive of an expanding albeit better managed forest industry.

In 1950 in an article simply titled "Trees" Bernard Magee describes their beauty, their romantic influence on poets and artists, and their pivotal role in sustaining "countless animals, insects, and birds..." (44). He explains furthermore, that forests need protecting for through their capacity to store water and regulate climate and rainfall, they "spread wealth to a spacious land" (44). Nineteen years after Callaghan urged the clearing of tea-tree the influential landscape designer and author of several books, Edna Walling, writes of being appalled by what she describes as the slaughter of Australia's paperbark and tea-trees, and passionately urges its conservation.

It is regrettable, to say the least, that it is so often slaughtered as so much valueless "scrub", a fate ignorantly meted out to so much of the native beauty of Australia. (24-25)

The relationship between landowners and the wedge-tail eagle provides another example of the equivocation and tensions between supporting the expressed interests of the rural sector and concern for protecting fauna. It was long held by many that wedge-tails were the scourge of young lambs even though contemporary research concluded that eagle predation on healthy lambs was a rare event 
(Apgar). ${ }^{7}$ Commencing in 1935 Walkabout began canvassing this issue. The collector A.F. Embury writes of the eagle's magnificence "the most picturesque and typically Australian of all the ..." native hawks - and notes a "belief" that the birds "are a menace to flocks and poultry" (16). He records this "belief" had seen many thousands killed, and lists various methods used by farmers and graziers to this end. One grazier boasted of having "trapped and killed one hundred and twenty eagles in twelve weeks". Given there was a bounty on eagles such killing was not without monetary recompense, but financial reward was not the eagle's primary threat. ${ }^{8}$ When describing to the grazier how he had found on another's property a nest of nankeen kestrels, whose diet comprises mostly mice and grasshoppers, Embury was surprised when asked if he had killed them. For this grazier all birds of prey were the potential predators of lambs (16-18).

The grazier had laboured hard to eradicate rabbits, and in Embury's day-long walk none were seen. In areas where rabbits were abundant and the number of smaller native animals considerably diminished due to grazing and farming activities - and competition from

7 In the 1960s the school bus of my early childhood followed a stock route. It was mostly sheep droved along this section (and only very occasionally cattle). Several farmers in the district, eking out a living on soldier-settler blocks carved from a formerly large station, raised sheep. On the fence alongside one stretch of the dirt road it was not unusual to see boastfully mounted and always with wings outstretched a wedge-tail eagle or two, and once three.

8 In 1935 the bounty was 2 shillings 5 pence per eagle (Upfield 26). Relative value is not a straightforward computation, however, using average earnings as the computational measure $2 \mathrm{~s} 5 \mathrm{~d}$ equates to approximately \$38AUD in 2010. For determinations of relative value, see: http://www.measuringworth.com/. In Western Australia bounties continued to be paid for eagles until 1968, and in Queensland until 1974. It was only removed from Western Australia's "vermin" list in 1989. Special "damages licences" are still obtainable in Western Australia which permit the destruction or removal of fauna, including the eagle, under certain circumstances. There is, however, no evidence that eagles prey on healthy lambs to any significant extent. A ten year survey in the 1960 s by the CSIRO concluded that eagles were responsible for less than $1 \%$ of lambs taken, some of which would almost certainly have died of other causes such as abandonment or illness (Apgar 2; see also Eric Rolls 298-299). 
more numerous and / or aggressive introduced fauna - rabbits had become a principal food for eagles. In successfully ridding his land of rabbits, Embury argues the grazier was responsible for eagles switching their predatory attention to lambs and poultry. Despite this, Embury does not criticise the grazier:

We can scarcely blame him if, having seen fit to go to the expense of cleaning up the one pest, he should be equally intent upon the extermination of the other. (17)

Although empathising with the lot of the grazier, Embury still cannot support their desired demise of the wedge-tail. He concludes though it might be sensible "to keep their numbers in check, it would certainly be a national sin to allow the species to be exterminated" (18). In contrast, in an article on rabbit and fox fur trappers contemporary with Embury's, Arthur Upfield, an astute and sensitive observer of the remote landscape and its people, makes little distinction between eagles, foxes and rabbits in his evocative and harrowing description of how each is trapped. Of the eagle Upfield does admit that "It is saddening to see these great birds thus destroyed, but any trapper's heart has long been hardened by their terrible attacks on newly-born, defenceless lambs" (26). ${ }^{9}$

Over the years Walkabout returned to this issue a number of times (see for example J.B. ${ }^{10}$ Chandler; Gigney; Tomkinson). But despite Walkabout marketing itself as Australia's "geographical magazine", it did not pursue definitive resolution of debates such as these. Its interests were more varied and nuanced than unabashedly throwing its support behind the lot of the farmer, pastoralist or miner, or as instanced above, the wedge-tail. It was inclusive of contradictory and competing concerns. Although generally supportive of development, in attempting to foster familiarity with Australia's natural beauty and native wildlife, and through that an appreciation for and

9 Such discussion and ambivalence over the extent of eagle predation on lambs was not confined to Walkabout. It was a current debate appearing in many fora, including in the early to mid 1930s in the pages of the Australian ornithological journal Emu (see Roberts; Anonymous; McGilp; Lansell). Although some writers to Emu argued eagles were a menace to even healthy lambs (see for example McGilp), most contributors agreed that such predation was rare.

10 The author used initials only and to date I've been unable to find the full name. 
love of country, articles urging the conservation of species and the better management of natural resources abound.

It was not just the more readily rhapsodised birdlife and iconic fauna like eagles, emus, koalas and crocodiles that Walkabout featured, although these were the subject of many articles and photographs. Numerous articles and notes described the characteristics and habitat of a vast range of flora and fauna, including varied reptiles, amphibians, macropods, monotremes, even fungi. Stanley Breeden's "Close up of a Forest Community" describes a "day in the life of creatures who live on, or under, the bark of trees within nine miles of Brisbane" (15). Spiders, insects and reptiles are the focus of his article.

The desert regions too provoked contrasting discussion. In 1935 in a descriptively titled article "Sand", Ion Idriess writes of the delicate beauty of the Australian desert, the life it nourishes, and of the changes undergone across millennia. Country once well-watered, forested and sweetly grassed, the rangelands of the megafauna, was now

our land of the night-parrot, of the burrowing mole, of the sightless snake, of things so elusive that they are no more than a hiss or a squeak in the night. (22)

His concern was not simply that in disturbing "the balance of nature" (23) through overstocking and the clearance of sparse vegetation that land (even country distant from the point of disturbance) was stripped of its productive potential. It was also that something uniquely valuable in and of itself was being irrevocably destroyed; even things that were "no more than a hiss or a squeak in the night." In 1948 Kathleen Woodburn found in the deserts a finely balanced, sensitive ecosystem checked from expansion by a lightly vegetated fringe. She critiques the pastoral industry for ignoring scientific advice and overstocking this constraining barrier. Woodburn argued its consequential destruction leads inevitably to the rapid desertification of formerly productive and beautiful country (32-34).

In contrast to Idriess and Woodburn, Michael Sawtell, a former drover, union organiser, Emersonian and staunch advocate for Aboriginal rights (Roe), wrote in anticipation of how the discovery of oil and technological intervention would render the Simpson Desert fertile and productive. This was the only arid region that Idriess (22) 
believed was still defying attempts to exploit it. Citing the aforementioned Bradfield's vision for watering inland Australia, Sawtell proclaims:

Oil is even more powerful than water. Roads, towns, local irrigation schemes from wells and tanks, and other improvements would follow the discovery of oil in the Simpson. ... [Its] discovery ... would have a great influence upon the dust problem and climatic conditions over an enormous area of eastern inland Australia. (35)

Not for Sawtell the need to rein in the excessive stocking of the pastoralists and the urging of more sympathetic exploitative practices. Instead he had faith in the capacity of the technologies of industrial modernity to overcome even the most challenging environmental constraints.

Four years earlier - in 1944 - the author and playwright Henrietta Drake-Brockman posited that water alone would bring the infrastructure and industry envisaged by Sawtell, and not just to the desert. Drake-Brockman was the wife of Geoffrey Drake-Brockman, who from the early 1920s (until 1941) was based in Broome as Commissioner (and subsequently engineer) for the Department of the North-West. In that capacity he urged the development of agricultural industries in the Kimberley - Ord River region (Cowan). Like Bradfield's vision for watering western Cape York and inland Australia, Henrietta Drake-Brockman wrote of the waters of the Ord emptying wastefully into the sea. Of the then recently proposed Ord River irrigation scheme she expounded:

Water means growth, growth means wealth, wealth means power. To-day water means also hydro-electric power, power means plant, plant means manufacture. The ever-widening circles of a single engineering achievement - however remote - can spread prosperity and comfort throughout an entire continent. (6)

Similarly to Sawtell, Drake-Brockman foresaw any problems that arose realising this prosperity being solved by the application of modern twentieth-century science (9).

A belief in the existence of almost limitless land suitable for irrigation is found throughout Walkabout. However, this position was not unchallenged. Gordon Wood, Professor of Commerce at the University of Melbourne (and influential advocate for journalists) warned in an article in 1949 of the cost of development where soil fertility is low and rainfall inadequate. He argued these costs could risk lower- 
ing the standard of consumption, and that improving efficiency on lands already in use would be more sensible.

The expensive and extensive development of areas which have been very slenderly endowed by nature for rural or other production would seem to be less justifiable than intensive development of the favoured regions already occupied and in process of development. (18)

Almost twenty years later, in "Water for a Thirsty Land: Bradfield Scheme had Flaws", Rhea Boldery pointed out that irrigation is not viable in arid areas. Further, she correctly described as "absurd" Bradfield's proposition that evaporation from large inland reservoirs created by diverting rivers would produce sufficient atmospheric moisture to bring rainfall to parched areas (Boldery 16-19; 18). Others not so much objected to, or even interjected in, the exhorttations for further development. Rather, in gently expressing misgivings they voiced concerns that brought into focus the subtle splendour of extant landscapes; sensory perceptions often overlooked in the bluster advocating progress. Such sensitivities can be found throughout Walkabout. They are not coincident with the emergent conservation and environmental movements of the mid to late 1960s. In an early edition of Walkabout (1935) and writing of Mildura's environs following the building of the lochs on the Murray River, Alice Lapthorne notes the greater productivity that irrigation brings, but regrets how it has destroyed much of the landscape's prior beauty. The richness of the riverine environment, a land and waterway hosting a profusion of wildflowers, and of ducks, frogs leeches, fish and bird calls and the domain of Aborigines, now grew just grapes and oranges. "The silence that was once unbroken, save for bird-calls and the croaking of frogs, is now shattered by the constant roar of water ..." (28).

\section{Literature, Imagining and Nationalism}

The examples above typify the sort of tensions and ambivalences that rattle their way throughout Walkabout, and through every single issue one way or another. It is easy to find in Walkabout a teleology, in which today's society was an inevitable outcome of and reward for faith in progress and modernity's capacity to deliver prosperity. In such a fashioning other concerns are diminished or contemptuously dismissed (after all, there were only birds and crocodiles in the soon-to-be-flooded gorges of the Ord River (see Drake- 
Brockman 10). However, to read Walkabout in this way is determinist, and is to ignore the contingent basis of ostensible historical trajectories and the range of possibilities open at any given time. The tensions betwixt advocacy for progress and concern for the environment and conservation, whether that concern be incidental or explicit, raises some of these possibilities.

Moreover, the significance of concerns divergent to more dominant themes should not be overlooked. Ivor Indyk, in his paper "On 'the Land' as a Relative Absolute", observes that in the literature of the "radical nationalists" writing between the wars in the 1930s-40s, "the land" is frequently perceived "as the source and repository of all that was essential about Australian identity and the Australian character." In the novels of Palmer, Prichard, Davison, Herbert, Dark, Eldershaw and Tennant, ostensibly the land represented a "fundamental truth, an absolute beyond which there could be no other reality" (Indyk 105). This work stands in contrast to that of Murnane and Malouf, who Indyk suggests adopt a postmodern outlook to notions of land so as to "challenge the fixity of identity and subjectivity" (105). But as Indyk proceeds to argue, a closer reading of the place of land in the work of the literary novelists of the thirties and forties reveals not the aforementioned fixities and nationalist certainties, but rather a testing of these values in contemporary circumstances. He finds "[t]he land invoked was not, as one might think, a land made fruitful or productive in its coming to nationhood" (106). The land represented an array of possibilities rather than a tableau upon which aggressive nationalist and imperialist agendas were inscribed. It is my contention that Walkabout too, whilst seeking to educate Australians and others about the Australian landscape (and its potential for development), was not reproducing hegemonic forms of radical nationalism, but more an ambivalence that was ripe with possibilities.

Indyk was writing about Australian literature. Walkabout on the other hand, was not literary in the conventional sense, but rather a magazine comprised of non-fiction "embarked on an educational crusade" to enlighten Australians about that which lay "beyond the cities" (Jones 7). Further, it favoured empirical works over armchair commentary. Walkabout then was concerned with facts, and to these ends it promoted itself as a "geographic magazine" presenting "the most interesting features of Australia and the South Seas". Al- 
ready leaning towards the natural sciences, in August 1946 it became "the official organ" of the newly formed Australian Geographic Society (AGS) and in 1947, with an interest in enhancing the "authoritative character of the magazine" its title was changed to Australian Geographical Magazine: Walkabout (ANPA 1947). ${ }^{11}$ Despite this, and anxious not to lose its established readership, Walkabout continued to publish articles (and accompanying illustrations) "in popular form" (ANPA 1950: 1).

It remains true, however, that for the most part works of non-fiction are spared the finely textured scrutiny of the literary critic. Non-fiction may be read for its politics, ideology, biases, facts (contested or otherwise) and a host of other things, but rarely for its "narrative strategies" and "rhetorical machinery" (Geertz 2). There are exceptions to this. Since the mid to late 1970s and influenced by Clifford Geertz's (amongst others) application of literary theory to works of anthropology these too have been read (and still are) through this critical apparatus. Anthropologists are now very aware of how the "literary character of anthropology" (Geertz 3) reveals the "imagery, metaphor, phraseology or voice" (Geertz 2) the "author" deploys to weight his or her data with authority. ${ }^{12}$ Although Walkabout magazine, in bringing knowledge of Australia's interior and remote areas to an urban-based and overseas readership only published non-fiction, many of its article-length contributions were carefully selected on the quality of their rhetorical style. This was important not only because of the intended educational role and reach of the magazine, but also because the majority of its readers (72\%) were in professional or skilled categories (ANTA 1961, 4). Despite being "dependent on free-lance writers of varying knowledge, ability and talent" (ANPA 1947), the editorial board consistently strived to maintain the general quality and readability of articles, and actively sought the contributions of some of mid-twentieth century's leading popular Australian writers, including Ernestine Hill, Mary Durack, Ion Idriess, Arthur Upfield, John K. Ewers, George Farwell, Henry Lamond and

11 The Australian National Travel Association (ANTA) changed its name to the Australian National Publicity Association (ANPA) on 16 December 1940. It reverted to its former name in 1955.

12 It is outside the scope of this paper to discuss why it is that the discipline of anthropology and the works that discipline "authors" are now so self-reflexive. 
the naturalist David Fleay. ${ }^{13}$ Such contributors amongst many more consciously engaged with the "theatre of language" (Barthes 192). They were not mere "writers" performing "an activity" in order "to give evidence, to explain, to instruct" (Barthes 189). For the purposes of rendering those interests of their concern sensible many of Walkabout's contributors employed the persuasive devices normally associated with literature.

In promoting the opportunity for hitherto unthought-of possibilities for "[w]hat 'Australia' means", Bill Ashcroft and John Salter argue for the primacy of creative writing, of "fictional narratives" (19). According to them, "literary writing is valuable":

because the "unknown" has yet to be imagined, and it is in that part of the textual fabric of Australia called literature that such an imagining can best be accomplished - imagining the place, imagining the self; imagining the self in place. (19)

Ashcroft and Salter see the 1994 Mabo decision, contemporary with the time they were writing, as producing the conditions in which the "rhizomic structure", that "concealed network of signification" linking various Australian cultural texts, would reveal a new and consequential understanding of Australia.

This reading/writing constitutes not simply the bringing to existence of the (new) text of the place "Australia" (one which supersedes terra nullius), but as well, and this is really what the post-Mabo debate is all about, a new awareness of conscious existence within this place. (22; their emphasis)

There is of course a tendency to find and privilege what one is looking for, but the sort of imagining that Ashcroft and Salter believe is now possible because of, or perhaps provoked by, the recognition of native title in Australia, can also be found in earlier literature; even in that literature aforementioned that is generally interpreted as being broadly nationalist. Crucially, the tensions apparent in Walkabout as discussed here, and for that matter tensions vis-à-vis Aborigines (see Rolls 2010a) and much else are also apparent, are a product of the very imagining desired by Ashcroft and Salter. This is not to try and privilege the critical reading of a popular magazine with its component works of non-fiction over that of literary fiction.

13 These authors alone - and the list is by no means exhaustive - contributed 245 articles to Walkabout. 
It is to argue the relevance of this and other such work in considerations of how Australia has been and is imagined.

It is ironic that Ashcroft and Salter envisaged an "imagining" of the "unknown" capable of producing new texts founded on the explicitly technical decision of the High Court and the legislative apparatus of the subsequent Native Title Act. These are the necessary instruments founding the imagination they foresaw and desired. In bringing information about the remote and rural regions of Australia, the people who lived there including Aborigines, and accessible details about native flora and fauna to its many urban readers, Walkabout too was promoting knowledge instrumental to any imagining of place. Looking back from the perspective of the mid 1960s, the historian Alec Bolton claimed that Walkabout "as much as anything else, discovered outback Australia to the popular imagination" (5). Considering the integral position of flora and fauna in Aboriginal epistemologies and the specialised knowledge that Aborigines possess of their environment, the pertinence of facilitating settler knowledge (and imagining) of place inclusive of these other presences (flora and fauna) cannot be underestimated. Ashcroft and Salter called for a fictional "imagining" of the "unknown" based on the belated recognition of factual native title. For decades Walkabout had already been providing the resources upon which "unknowns" - remote landscapes, native flora and fauna - could also be imagined, based on a more thorough understanding of presences, which like native title, pre-existed settler society, and which like native title, most were ignorant of.

Walkabout therefore provided a glimpse into the disparate constituencies of different environments in which Aborigines had long been "imagining [themselves] in place." This is not to suggest that these glimpses fostered contiguity between settler and Aboriginal imaginings of place, but knowledge of what is actually there is fundamental to any imagining of how to perceive it, and crucial to any awareness of the need for something's conservation. This holds as true for knowing of the existence of native title as it does for knowing of the existence of the night parrot and the burrowing mole. For a start and most obviously, the so-called "dead heart" of Australia was not 
quite so dead after all, a reality very familiar to Walkabout's readers. ${ }^{14}$

\section{Genre Shifts and Boundary Lines}

In her study of nineteenth-century Victorian novels, Suzanne Keen identifies what she calls "narrative annexes". These function to "allow unexpected characters impermissible subjects, and plot-altering events to appear, in a bounded way, within fictional worlds that might be expected to exclude them" (1). Victorian novelists, therefore, employed the device of the annexe to address issues and anxieties that would be otherwise unacceptable. Narrative annexes differ from satellite and more incidental events and temporary changes of setting in that the former are "consequential for the plot", whereas the latter do not disturb the plot's overall direction $(3,6)$. Keen also distinguishes annexes from other ever present devices such as the inclusion of contrasting voices, or the additional information provided by a second narrator or some other supplementary source (7).

As evidenced above, many of the articles in Walkabout in their incidental mention of environmental concern of one sort or another are not utilising an annexe-like device to introduce difficult or impermissible subject matter. A sentence or two, whilst perhaps giving a reader pause for reflection (a contrasting voice?), does not replace the norms otherwise iterated in the body of an article. They are largely inconsequential to the narrative plot. If, however, we con-

14 By the 1930 s a number of popular authors were contesting the metaphor of Australia's "dead heart," most notably the zoologist H.H. Finlayson (1935) in The Red Centre, R.H. (Bob) Croll (1937) in Wide Horizons and Ernestine Hill (1940) in The Great Australian Loneliness. Hill proclaims "[t]he allegedly 'dead heart of Australia' is vitally alive" (247) and her desert section, contained in "Book III", is titled "The Living Heart" (245). Both Croll and Hill amongst many others contributed articles on the centre to Walkabout. See for example Croll (1934); Croll (1939); Hill (1935). On the imaginative shift from the "dead heart" to the vibrant "red centre" see also Tom Griffiths (1996: 176-192); Roslynn Haynes (1998: 143-160). Significantly Walkabout also included many feature articles about, incidental commentary on and photographs of Australia's Pacific and northern neighbours, thereby assisting the capacity of readers to apprehend Australia's regional location. 
sider Walkabout in its entirety as a text, ${ }^{15}$ and one interested in the rhetorical machinery of narrative in its capacity to drive apperceptions of place, we do find annexes in the form of provocative departures. These furnish strong and clear delineations of alternative ways of seeing the landscape and interventions that breach the championing of progress. There exist narrative structures and rhetorical machinery arguing a different ethic.

These would include, in addition to the more literary contributions in popular style, the many notes on natural science and the letters and responses concerned with the accurate identification of species (snakes to take but one example). For the most part these contributions do not contain imaginative flourishes, but description alone of a variety of Australia's unique flora and fauna. There are notes concerning entomology, ornithology, herpetology, and ichthyology; native bees, geckoes, spiders, angler fish, grass trees, and so on. The act of recognising the presence of these natural features, some conventionally beautiful but others not so, helps pack the landscape with considerations that might prove an impediment to unfettered progress. The inclusion of natural history through these descriptive notes, letters and articles, highlights presences other than gold, coal, silver, oil, osmiridium, copper, tin, iron ore, uranium, mica, tungsten, wool, cattle, fish, wheat, barley, oats, hops, apples, pineapples and bananas, all of which amongst much else also feature in Walkabout. Considered with those articles explicitly concerned with conservation, this natural history miscellany constitutes genre shifts in the overall text of Walkabout that function in a similar way to the annexes Keen discerns in nineteenth-century Victorian novels.

Annexes are initiated by a combined shift in genre and setting that changes the fictional world of the novel, and they work by interrupting the norms of a story's world, temporarily replacing those norms, and carrying the reader, the perceiving and reporting characters, and the plot-line across a boundary and through an altered,

15 A significant number of Walkabout readers were reading the magazine in its entirety, and were doing so over a number of years. A November 1961 reader survey found that in the preceding seven months $70 \%$ of respondents had read every issue. More anecdotally, readers commented that "We read Walkabout from cover to cover and enjoy it very much." Some of the respondents had been subscribing to the magazine for nearly two decades (ANTA 1961: 4). 
particular, and briefly realised zone of difference. In small spaces and few pages, narrative annexes challenge both cultural and literary norms to form imaginative worlds more variously, in sometimes distracting or dissonant interludes. (1)

This is precisely the role of the material in Walkabout discussed here. The ostensible norms of progress, of peopling and watering the continent, of forever increasing primary production, of celebrating instances of winning-the-battle-against-nature and the "thunder of dynamite" and the "fat plop of concrete" (Drake-Brockman 10), are temporarily displaced by a shift in genre to natural history and the foregrounding of concerns for conservation. These "dissonant interludes" challenge cultural norms to "form imaginative worlds more variously", and in doing so, facilitate a reimagining of place. Keen writes that narrative annexes "reveal not only the effort to employ alternative representational strategies, but also the subjects that instigate that effort" (1-2). Recognition of the delicacy and vulnerability of the Australian environment (prescient in many instances) and all that dwells on, in and above it, was the subject matter propelling the narrative strategies that challenged the norms of the dominant story.

The significance of these "interludes" and their capacity to disturb, disrupt or challenge the dominant story are often misunderstood, ignored or dismissed. Rather than finding disruption, Jillian Barnes finds instead incoherence. Relying extensively on articles in Walkabout, she states that "ANTA's productions were always to some degree incoherent. Some writers, for example, acknowledged modes of Aboriginal spatiality ... while others fostered a non-combative view of Nature" (166). According to Barnes, such "incoherence" ultimately did not disrupt ANTA's contribution to "a legitimating narrative long used by Europeans around the world to ratify conquest and dignify their possession of land" (156). In a critique of Walkabout's first fifteen years Glen Ross argues that it was a nationalist vehicle promoting an exclusionary form of progress that was white, mono-cultural and masculine (Ross; see also Barnes). Not only does this argument not withstand scrutiny vis-à-vis Aborigines (see Rolls 2010b), the broader sweep of the magazine does not imagine into being such an Australia, or at least, not that alone and not without contention. Indyk, in discussing the novels of the aforementioned "radical nationalists" - or "liberal humanists" as they are also sometimes labelled (see Indyk 110) - of the 1930s-40s, finds their invocation of 
the Australian landscape more complex, intricate and responsive to contemporary vicissitudes than many critics allow. He finds "nothing imperial ... and virtually no sense of a national destiny" (113) in their invocation of the landscape. The novels' iterating of the "pioneering condition", sometimes explicit, sometimes implicit, is not to imagine a resplendent future arising from such a foundation, but rather a "testing of the social values" of the pioneering era. As Indyk suggests this was an understandable reaction to the between-the-wars social upheavals being experienced both in Australia and abroad (113).

Walkabout too, in its own way, was testing the social values of yesteryear. That it does so is not immediately apparent, for its focus on rural, regional and remote Australia ostensibly places Walkabout at a remove from the socio-cultural milieu of the increasingly cosmopolitan cities where these values were more explicitly under challenge. But the novels Indyk is discussing are also concerned with landscape, and some of these "favour the marginal setting, at the edge of settlement, face to the wilderness, the forest, the sea, the saltbush plains" (Indyk 106), which is very much Walkabout's terrain. Clearly Walkabout was interested in assisting to bring these areas of Australia into productivity, or increasing what little there already was, and in doing so further integrating them into a more aggressive form of socio-political and socioeconomic nationalism (see Indyk 107). However, Walkabout's embrace of pastoral and agricultural industrialism, promotion of tourism, and advertisements for luxuries amongst much else, spoke of the need for different social values to those held by man-with-axe subduing his domain. So too did concern for the water rat, the brush turkey, the blind snake, the burrowing mole, the insects and spiders in the forests close to Brisbane, as did concern over expansion of the deserts and general environmental degradation.

\section{Conclusion}

Walkabout's focus was more bucolic than urban, and more natural science and history than any of the arts. Its production values (at least until the 1960s) were very high and the quality of included imagery superb (it employed a staff photographer). In character its carriage and conduct was modest and it went about its business without pretension. Although one of its founding aims was to bring 
to littoral-dwelling Australians (and others) knowledge of the natural features of the Australian continent, its peoples and varied pastoral industries, and to render the unseen familiar and appreciated, it wore its nationalism lightly. Instead of promoting an insular and strident pride Walkabout attempted to foster through education and understanding a more enduring and inclusive delight in one's country. It also promoted development and progress. Articles speaking about the need for a greater population, faith in science to counter all obstacles, grand schemes for water, were all enthusiastically covered. This was especially so in the post war "nation building" era when Walkabout began to favour the scientist over the naturalist. As argued by Fetherstonhaugh:

For the naturalist, attention to the living animal or plant in its entirety within its natural surroundings was an end in itself ... [where] a primary focus remained the understanding of a "fellow creature" through direct experience in the field rather than through laboratory work. By the end of the 1940s fewer articles in Walkabout presented this perspective and proportionately more exhibited a reverence for the scientist and the power of science to solve "problems" of the natural world. These articles did not have about them the romantic celebration of Australian flora and fauna displayed by the naturalist but instead emphasised the potential of science to arrive at solutions to impediments in the utilisation of Australian natural resources. (310-11)

But the change in emphasis was subtle. Articles by naturalists continued to be included; so too were articles exhorting the conservation of species and greater protection for fragile environments. These interests were not lost on readers. Writing in 1970 from Hampton, Victoria, to the "mail bag" column of Walkabout P.S. Corr declared "Walkabout has never been quiescent about the need to conserve Australia's natural resources ..." (3). Although Walkabout had from the late 1960 s adopted a more explicit interest in conservation and environmental protection, one consequence perhaps of a more scientific approach, and Corr's appraisal may have been influenced by more contemporary issues, the magazine had continued to include articles throughout every decade that described in some way Australia's flora and fauna, and concern for its welfare. Even those letters and notes that owed more to scientific description or matters of taxonomy than "romantic celebration" of "fellow creatures" provide a narrative distinctive to those advocating progress and foreseeing the rise of a modern industrialised nation. An instance of this is a series of "Nature Diary" columns by Donald Thomson. The Ja- 
nuary 1950 edition, for example, describes under the respective headings of "Pouched Mice", "The Ant Lion" and "More about the Taipan", the small rodents of the Phasogale species found in southeastern Australia, the larval stage of the ant lion and discussion on the identification of taipan snakes (Thomson). Whilst concerned with accurate description, Thomson nevertheless wrote in a style accessible to the lay reader and frequently leavened the descriptive details with anecdote. This was typical of contributions describing Australia's flora and fauna, even in the post war environment when a more scientific approach gained favour. It is evident throughout the many contributions of the scientist and naturalist David Fleay who wrote for Walkabout for over twenty years (1937-1958), covering such topics as gliding "squirrels" (Fleay 1937), breeding the water rat (Fleay 1948) and the red-bellied black snake (Fleay 1953). Personal field experience features to a greater or lesser extent in nearly all such contributions, the like of which can be found throughout the five decades of Walkabout magazine.

Discussing the various industries (forestry, mining, tourism, fishing, agriculture, horticulture amongst others) and the multiple ways in which they intersect that are constitutive of Australia's rural economies Gorman-Murray, Darian-Smith and Gibson note that "the cultural construction of the Australian rural must now accommodate a fluid and diverse range of landscapes, livelihoods and industries" (40). From 1934 onwards Walkabout certainly captured all of these, both in print, photograph and illustration. The Australia Walkabout imagined, therefore, was one of contrasting and conflicting values, where the exhorted vector of progress was recognised as a compromise of competing desires and interests, and where contradiction was not foreclosed but left open. In bringing the ferment of multiple landscapes and the diversity of life they harboured, including human, to urban Australia, Walkabout provided the foundation for readers to form their own "imaginative worlds more variously" (Keen 1). For a magazine on an "educational crusade" with the founding objective of informing a predominantly urban, middleclass readership about that which lay beyond the cities, this is a laudable achievement. ${ }^{16}$

16 The reader survey conducted in 1961 revealed that only 7 per cent of readers fitted the survey's "rural" category, and 72 percent were en- 


\section{Works Cited}

Anonymous, 1936. "What of Our Raptores?". Emu 35(4), 348-350. Apgar, Marra, 2003. "Damages Licenses for Wedge-Tailed Eagle Take: Position Statement of the Society for the Preservation of Raptors Inc". 1-4. http://www.raptor.org.au/wte_posn.pdf (Accessed 2 March 2012).

Ashcroft, Bill; Salter, John, 1994. "'Australia': A Rhizomic Text", in: Dobrez, Livio, ed., Identifying Australia in Postmodern Times. Canberra: Bibliotech, 15-23.

Australian Broadcasting Corporation, 2010a. "Nation's Food Bowl". The 7.30 Report, Australian Broadcasting Corporation, Broadcast 28 September 2010. http://www.abc.net.au/7.30/content/ 2010/s3024352.htm (Accessed 25 June 2011).

Australian Broadcasting Corporation, 2010b. PM. Australian Broadcasting Corporation, 2010. http://www.abc.net.au/pm/content/ 2010/s2993407.htm (Accessed 25 June 2011).

Australian National Publicity Association, 1947. "Agenda Notes for Australian National Publicity Association Board Meetings Sydney, 17th February 1947, p.4. Comprising Appendix ' $A$ ' for Australian National Publicity Association, Minutes of Board Meeting Held at Melbourne on 15th August, 1946, No.1, 21-22". Sydney: Mitchell Library ML550/05, Beresford Box 2(43).

---, 1950. "Australian Geographical Society Minutes No. 10 Financial Year Ended 31 May 1950. The Australian Society Bulletin No.10 1st October, 1949, p.1". Sydney: Mitchell Library ML550/05, Beresford Box 2(43).

Australian National Travel Association, 1929. "No.1 Record of Business Transacted at Inaugural Meeting of Committee Held in Sydney on 25th March, 1929". Sydney: Mitchell Library ML550/ 05, Beresford Box 4(43).

---, 1961. "Getting to Know Walkabout Readers: A Study of the Characteristics and Reading Habits of Walkabout Readers". News and Information Bureau: Tourism - ANTA [Australian National Travel Association] Board, Canberra: National Archives, N62/116, Canberra.

gaged in professional occupations (including administrative roles, teaching, students and skilled work) (ANTA 1961). 
---, 1966. "Australian National Travel Association Annual Report 1965'6: Marketing; Walkabout Magazine". Sydney: Mitchell Library ML550/05, Beresford Box 4(43).

---, 1971. "Pending Letters", Walkabout Records, 1959-1971, Sydney: Mitchell Library MLMSS7761 2(2).

"Australia and the South Seas in Pictures", 1942. Walkabout, 8(11), 17-24.

Barlow, Christopher, 1942. "Down Come the Trees". Walkabout, 8 (11), 32-33.

Barnes, Jillian, 2011. "Tourism's Role in the Struggle for the Intellectual and Material Possession of 'The Centre' of Australia at Uluru, 1929-2011". Journal of Tourism History, 3(2), 147-176.

Barthes, Roland, 1993. "Authors and Writers", in: Sontag, Susan, ed., A Barthes Reader. London: Vintage, 185-193.

Boldery, Rhea, 1967. "Water for a Thirsty Land". Walkabout, 33(5), 16-19.

Bolton, A.T., 1964. "Preface", in: Bolton, A.T., ed., Walkabout's Australia: An Anthology of Articles and Photographs from Walkabout Magazine, Sydney: Ure Smith, 5-6.

Bradfield, John J.C., 1941. "Rejuvenating Inland Australia". Walkabout, 7(9), 6-15.

Breeden, Stanley, 1960. "Close up of a Forest Community". Walkabout, 26(3), 15-18.

Callaghan, Allan R., 1948. "From Tea-Tree Swamp to Pasture". Walkabout, 14(10), 29-32.

Cathcart, Michael, 2002. "Uluru", in: Bonyhady, Tim and Griffiths, Tom, eds., Words for Country. Sydney: University of New South Wales Press, 207-221.

Chandler, Leslie G., 1944. "Some Mallee Birds of Prey". Walkabout, 10(12), 13-16.

Corr, P.S., 1970. "Conservation Conscience". Walkabout, 36(2), 3. Cowan, Peter, 1996. "Drake-Brockman, Henrietta Frances (19011968)". Australian Dictionary of Biography. Canberra: National Centre of Biography, Australian National University, http://adb. anu.edu.au/biography/drake-brockman-henrietta-frances-10683/ text17719 (Accessed 31 January 2013).

Croll, Robert Henderson, 1934. "Inland Oddities". Walkabout, 1(2), 37-43, 57.

---, 1937. Wide Horizons: Wanderings in Central Australia. Sydney: Angus \& Robertson (Second ed). 
---, 1939. "On the Edge of the Wild: A Camp with the Arunta". Walkabout, 5(4), 17-20.

Curtis, R. Emerson, 1942. "Phalangers". Walkabout, 8(11), 30-31.

---, 1947. "No Rest for Australian Forests". Walkabout, 13(12), 2935.

Drake-Brockman, Henrietta, 1944. "Water Means Wealth". Walkabout, 10(12), 4-11.

Embury, A.F., 1935. "The Wedge-Tailed Eagle". Walkabout, 1(10), 16-18.

Ewers, John K., 1940. "Yampi Sound and Its Iron". Walkabout, 6(6), 8-16.

Fetherstonhaugh, Timothy John, 2002. "The Journal Walkabout and Outback Australia 1930s-1950s: A Romantic Rapprochement with the Landscape in the Face of Modernity". Unpublished PhD Thesis, Murdoch University, Perth.

Finlayson, H.H., 1935. The Red Centre: Man and Beast in the Heart of Australia. Sydney: Angus \& Robertson.

Fleay, David, 1937. "Furry Gliders among the Giant Gums: Intimate Glimpses of Australia's Beautiful Nocturnal 'Flying Squirrel'". Walkabout, 3(8), 13-19.

---, 1948. "Breeding the Shy Water Rat". Walkabout, 14(9), 18-20.

---, 1953. "The Red-Bellied Black Snake". Walkabout, 19(9), 12-14.

Geertz, Clifford, 1988. Works and Lives: The Anthropologist as Author. Stanford: Stanford University Press.

Gigney, M.E., 1955. "Eagle Trapping". Walkabout, 21(11), 42, 45.

"Goanna", 1940. Walkabout 6(6), Front Cover (unattributed).

Gorman-Murray, Andrew; Kate Darian-Smith, and Chris Gibson, 2008. "Scaling the Rural: Reflections on Rural Cultural Studies". Australian Humanities Review 45, 37-51.

Griffiths, Tom, 1996. Hunters and Collectors: The Antiquarian Imagination in Australia. Cambridge: Cambridge University Press.

Harvey, Dorothy, 1940. "Podargus, the Frogmouth". Walkabout, $6(6), 38$.

Haynes, Roslynn D., 1998. Seeking the Centre: The Australian Desert in Literature, Art and Film. Cambridge: Cambridge University Press.

Hill, Ernestine, 1935. "Mining Mica in Central Australia". Walkabout, $1(9), 37-38$.

---, 1940 [1937]. The Great Australian Loneliness. Melbourne: Robertson and Mullens Ltd, 2nd ed. 
Holmes, Charles, 1932. We Find Australia. London: Hutchinson.

Idriess, Ion L., 1935 "Sand: Impressions of a Large Tract of Dry Country in the Interior of Australia". Walkabout, 1(11), 22-24.

Indyk, Ivor, 1994. "On 'the Land' as a Relative Absolute", in:

Dobrez, Livio, ed., Identifying Australia in Postmodern Times.

Canberra: Bibliotech, 105-114.

Jackson, Andrew, 1830. "Andrew Jackson's Second Annual Address

to Congress". Civics On-Line. http://www.civics-online.org/ library/formatted/texts/indian_removal1.html (Accessed 1 September 2010).

J.B, 1939. "The Wedge-Tail Eagle: Can it Lift a Lamb". Walkabout, 5(3), 63-64.

Jones, Chas. Lloyd Jones, 1934. "The Why and Wherefore". Walkabout, 1(1), 7.

Keen, Suzanne, 1998. Victorian Renovations of the Novel: Narrative Annexes and the Boundaries of Representation. Cambridge: Cambridge University Press.

Lansell, G.L., 1936. "A Few More Notes on Wedge-Tail Eagles and Notes on Ravens". Emu 36(3), 246-247.

Lapthorne, Alice M, 1935. "Murray Memories". Walkabout, 2(1), 28. Magee, Bernard, 1950. "Trees". Walkabout, 16(8), 41-42,44.

McGilp, J. Neil, 1936. "Wedge-Tailed Eagles". Emu 36(2), 99-102.

Patterson, Ewen K., 1940. "The Mighty Devil-Ray". Walkabout, 6(6), 19-20.

Roberts, N.L., 1935. "The Slaughter of Eagles". Emu, 35(1), 102103.

Roe, Jill, 2005. "Sawtell, Olaf (Michael) (1883-1971)". Australian Dictionary of Biography. Canberra: National Centre of Biography, Australian National University.

Rolls, Eric C., 1984 [1969]. They All Ran Wild: The Animals and Plants That Plague Australia. Sydney: Angus \& Robertson.

Rolls, Mitchell, 2010a. "Finding Fault: Aborigines, Anthropologists, Popular Writers and Walkabout". Australian Cultural History, 28(2-3), 179-200.

---, 2010b. "Reading Walkabout in the 1930s". Australian Studies, 2, 1-15.

Ross, G., 1999. "The Fantastic Face of the Continent: The Australian Geographical Walkabout Magazine". Southern Review, 32(1), 27-41.

Samuel, Edward, 1940. "Australian Petrol". Walkabout, 6(6), 29-32. 
Sawtell, Michael, 1948. "The Battle of Simpson Desert". Walkabout, 14(4), 34-35.

Spearritt, Peter, 1979. "Bradfield, John Job Crew (1867-1943)".

Australian Dictionary of Biography. Canberra: National Centre of Biography, Australian National University. http://adb.anu.edu. au/biography/bradfield-john-job-crew-5331/text9011 (Accessed 23 June 2011).

Thomson, Donald F., 1950. "Nature Diary". Walkabout, 16(1), 3435.

Tomkinson, Joan, 1959. "The Year of the Wedge-Tailed Eagle". Walkabout, 25(8), 18.

Upfield, Arthur W., 1935. "Trapping for Fur". Walkabout, 1(11), 2530.

Walling, Edna, 1967. "Spare the Tea-Trees". Walkabout, 33(2), 2425.

Wood, Gordon Leslie, 1949. "The Metes and Bounds of Australian Development". Walkabout, 15(9), 10-18.

Woodburn, M. Kathleen, 1948. "The Australian Deserts". Walkabout, 14(12), 32-34. 